\title{
ANALISIS EFEKTIVITAS SISTEM INFORMASI AKUNTANSI PENGGAJIAN KARYAWAN PADA PT. KERISMAS WITIKCO MAKMUR FACTORY BITUNG
}

\author{
Maya Ariesti Vinastri ${ }^{1}$, Jenny Morasa ${ }^{2}$, Sonny Pangerapan ${ }^{3}$ \\ ${ }^{1,2,3}$ Jurusan Akuntansi, Fakultas Ekonomi dan Bisnis, Universitas Sam Ratulangi, Jl. Kampus Bahu, Manado, \\ 95115, Indonesia
}

E-mail : mayaariesti.ma@gmail.com

\begin{abstract}
The quality of human resources can be improved along with the implementation of the system implemented by the company. The payroll accounting system is a system that can handle and report transactions, as well as salary payment procedures for both monthly and daily performance. This study aims to determine the effectiveness of the payroll accounting system applied at PT. Kerismas Witikco Makmur. This type of research is descriptive qualitative by taking primary data directly through interviews with 10 respondents on the object of research. The results of the study show the payroll system applied by PT. Kerismas Witikco Makmur still uses a manual system and there has been a clear division of tasks within the company.
\end{abstract}

Keywords: Effectiveness, Accounting Information Systems, Payroll, Employees

\section{PENDAHULUAN}

Dunia perekonomian saat ini sudah sangat maju dengan berbagai persaingan yang ketat di antara perusahaan-perusahaan di tingkat lokal, nasional dan bahkan di tingkat internasional. Persaingan tersebut semakin terasa dengan dimulainya era globalisasi dan hal tersebut menjadi tantangan tersendiri bagi perusahaan-perusahaan besar, menengah dan kecil di berbagai negara seperti di Indonesia. Berbagai aspek yang ikut berpengaruh terhadap kesiapan dunia usaha dalam mengahadapi persaingan tersebut adalah faktor manusia atau sumber daya manusia dan sistem yang digunakan dalam menjalankan operasional perusahaan. SDM atau tenaga kerja yang nantinya akan menjadi salah satu faktor pencapaian keuntungan dalam perusahaan, seharusnya menjadi fokus utama dalam perusahaan. Oleh sebab itu, dalam pembayaran gaji dan upah karyawan diperlukan suatu pengendalian biaya yang secara rutin harus diperhatikan oleh perusahaan. Manajemen adalah tingkatan yang akan bertanggung jawab atas pengendalian biaya tersebut.

Sistem adalah serangkaian bagian-bagian yang saling terkaitdan berinteraksi dalam mencapai suatu tujuan (Romney dan Steinbart, 2015:3). Sedangkan menurut Azhar Susanto (2013:22) sistem dapat dikatakan sekelompok komponen yang saling bekerja secara harmonis untuk mencapai tujuan perusahaan. Setiap perusahaan pasti memiliki sistem yang diatur dalam peraturan tertulis maupun tidak tertulis dalm suatu organisasi. Dalam suatu perusahaan, sistem akuntansi penggajian menjadi sangat penting dalam pengambilan keputusan para pengguna informasi. Terjadinya kesalahan pada informasi yang tersedia menyebabkan laporan keuangan yang dihasilkan menjadi kurang teliti. Sistem penggajian sangat penting dalam suatu perusahaan, karena digunakan untuk pembayaran balas jasa karyawan yang telah bekerja.

Sistem akuntansi penggajian adalah fungsi serta organisasi juga laporan mengenai penggajian karyawan yang dibayarkan setiap akhir bulan yang dibuat dengan sebaik-baiknya dalam mempermudah pengelolaan perusahaan (Baridwan, 2012). Sistem akuntansi penggajian dirancang untuk menangani setiap pencatatan dan pembayaran gaji karyawan dam suatu perusahaan. Sistem ini terdiri atas beberapa jaringan prosedur yaitu: prosedur 
pencatatan waktu hadir, prosedur pembuatan daftar gaji, prosedur distribusi biaya gaji, prosedur pembuatan bukti kas keluar, dan prosedur pembayaran gaji (Mulyadi, 2016:385).

PT. Kerismas Witikco Makmur adalah perusahaan yang bergerak di bidang manufaktur. Perusahaan ini menghasilkan produk berupa atap seng, genteng metal dan produk-produk untuk pembangunan perumahan, gedung-gedung, bangunan pabrik dan lainlain. Perusahaan yang berkantor pusat utama di Jakarta ini, membuka cabang di Manado, Sulawesi Utara, sedang pabrik sendiri terletak di Kota Bitung, Sulawesi Utara. Sebagai perusahaan yang memiliki SDM atau pekerja yang tidak sedikit, PT. Kerimas Witikco Makmur ini kadang mengalami ketidaktelitian dalam mengatasi permasalahan sistem penggajian dalam perusahaan. Adapun tujuan dari penelitian ini yaitu untuk menganalisis sistem penggajian yang diterapkan pada PT. Kerismas Witikco Makmur Factory Bitung sudah efektif.

\section{TINJAUAN PUSTAKA}

Sistem Akuntansi. Menurut Mulyadi (2016:2), sistem adalah sekelompok unsur yang erat dan saling berhubungan dengan sesama unsur, dan bersama-sama mencapai tujuan perusahaan. Baridwan (2012:3) juga berpendapat bahwa sistem merupakan suatu kerangka prosedur yang saling berkaitan dan dibuat menurut skema dalam pengambilan keputusan perusahaan. Menurut Yakub (2012:1), sistem adalah bagian dalam suatu organisasi yang memiliki tujuan yang sama dan merupakan jaringan kerja bagi setiap prosedur yang dijalankan. Menurut Reeve, Warren, dan Duchac (2011:9), akuntansi memiliki pengertian sebagai sistem yang dapat mengukur dan menginterpretasikan laporan keuangan.

Informasi. Di dalam bukunya yang berjudul "Accounting Information Systems" (2012:18), Gelinas dan Dull menuliskan bahwa informasi adalah data yang ditampilkan berbentuk formulir dalam rangka pengambilan keputusan perusahaan. Dengan kata lain, informasi merupakan suatu keterangan yang digunakan oleh pimpin dalam mengambil keputusan.

Sistem Akuntansi Penggajian. Sistem informasi akuntansi merupakan kumpulan dari sumber daya yang ada, yakni diantaranya manusia, softskill, bahkan peralatan untuk digunakan dalam mengubah data keuangan menjadi data lain yang berguna pagi pengguna informasi (Bodnar \& Hopwood, 2010). Rivai (2010: 762) berpendapat bahwa gaji adalah balas jasa yang seharusnya diterima setiap karyawan sebagai bagian dalam suatu perusahaan dan memberikan kontribusi dalam rangka mencapai tujuan organisasi. Pada dasarnya sistem akuntansi penggajian digunakan untuk mengawasi setiap transaksi yang terkait dengan gaji dan upah karyawan baik secara bulanan maupun harian. Adapun juga dalam sistem informasi penggajian terdapat pengendalian internal yang digunakan sebagai kebijakan dalam perlindungan aset perusahaan dari pihak-pihak yang tidak bertanggung jawab dan memastikan setiap aturan yang dibuat, diterapkan pula oleh setiap karyawan (Hery, 2014:11).

\section{METODE PENELITIAN}

Jenis Penelitian. Jenis penelitian ini termasuk dalam penelitian evaluasi atau dikategorikan dalam metode penelitian kualitatif dengan menggunakan metode studi kasus yaitu mempelajari secara mendalam dengan maksud mengungkap semua variabel yang dapat menyebabkan terjadinya kasus tersebut dari berbagai aspek (Walgito, 2010). Adapun tujuan yang ingin dicapai dari pengguna metode kualitatif yaitu, suatu penelitian dengan cara menggambarkan secara sistematis tentang analisis efektivitas sistem informasi akuntansi penggajian karyawan pada PT. Kerismas Witikco Makmur Factory Bitung.

\section{Jenis dan Sumber Data}

Jenis Data. Data yang digunakan untuk penelitian ini berupa data kualitatif yang diperoleh dari PT. Kerismas Witikco Makmur. Data kualitatif yang akan diperoleh dari perusahaan 
manufaktur ini, berupa gambaran umum dan sejarah perusahaan, struktur organisasi PT. Kerismas Witikco Makmur, dan data sistem informasi akuntansi penggajian karyawan perusahaan.

Sumber Data. Adapun yang menjadi sumber data primer dalam penelitian ini melalui kuesioner dan wawancara peneliti dengan Accounting Department dan Operation Senior Manager pada PT. Kerismas Witikco Makmur.

Metode Pengumpulan Data. Metode pengumpulan data dalam penelitian ini, adalah sebagai berikut :

1. Wawancara dilakukan bersama para direksi PT. Kerismas Witikco Makmur. Dari teknik ini, tentunya data yang diperoleh adalah data primer karena diperoleh dari sumbernya secara langsung.

2. Dokumentasi. Dalam suatu penelitian, dokumentasi identik dengan foto atau gambar. Namun perlu diketahui, dokumentasi dalam penelitian ini bukan saja hanya berupa foto atau gambar. Selain gambar dan foto, dokumenyang berupa catatan-catatan yang tersimpan diantaranya catatan transkrip, buku, surat kabar juga merupakan metode dokumentasi yang diperoleh dari suatu perusahaan. Adapun data yang dikumpulkan melalui metode dokumentasi pada penelitian ini berupa gambaran umum perusahaan dan data sistem informasi akuntansi penggajian karyawan.

Proses Analisis. Analisis data adalah upaya yang dapat digunakan dengan bekerja dengan data yakni, mengolah, mencari, menemukan pola yang penting untuk disampaikan kepada pengguna informasi (Moleong, 2013:280-281). Adapun proses analisis data dalam penelitian ini : (1) Pengumpulan data; (2) Reduksi data; (3) Penyajian data; dan (4) Perhitungan persentase efektivitas sistem informasi akuntansi penggajian dengan metode Champion. Analisis data yang dilakukan untuk mengetahui efektivitas sistem informasi akuntansi penggajian dengan penggunaan rumus Champion, yaitu dengan menghitung jumlah jawaban "Ya" kemudian dilakukan perhitungan dengan cara sebagai berikut:

$$
\frac{\text { Jumlah jawaban "Ya" }}{\text { Jumlah seluruh jawaban responden }} \times 100 \%
$$

Hasil jawaban yang diperoleh dengan cara perhitungan berupa skor berguna untuk pengambilan simpulan.

\section{HASIL PENELITIAN DAN PEMBAHASAN}

\subsection{Hasil Penelitian}

Deskripsi Sistem Penggajian pada PT. Kerismas Witikco Makmur. Kegiatan sistem penggajian yang dilakukan PT. Kerismas Witikco Makmur yaitu diawali dari karyawan masuk sesuai dengan jam kerja yang telah ditentukan dan menggunakan presensi yakni sidik jari (fingerprint). Data jam masuk dan pulang karyawan yang telah terekam pada fingerprint akan direkap dalam bentuk data setiap akhir bulan. Bagian Personalia yang mengecek dan mengelola masing-masing hasil presensi kehadiran yakni melalui fingerprint, akan memasukkan setiap data ke dalam Microsoft Excel. Data yang dimasukkan berupa data jam kedatangan dan jam pulang, juga data mengenai keterlambatan dan ketidakhadiran karyawan pada hari tersebut. Melanjutkan proses dari fingerprint ini, bagian keuangan mengambil acuan data dari bagian personalia, dan melanjutkan proses data yang menjadi salah satu unsur dalam sistem penggajian. Bila sudah, data tersebut kemudian dikembangkan menuju data penggajian karyawan sesuai jabatan dan status karyawan untuk menghasilkan laporan draft gaji dan slip gaji karyawan. Setelah bagian personalia memasukkan data dan memverifikasinya kembali, bagian personalia membuat daftar gaji dan slip gaji yang kemudian dikirimkan ke bagian akuntansi dan proses selanjutnya. 
Fungsi-fungsi dalam Sistem Akuntansi Penggajian pada PT. Kerismas Witikco Makmur

1. Fungsi Kepegawaian. Bagian ini bertanggung jawab dalam pengangkatan pegawai, penempatan jabatan, tarif gaji, pemberhentian pegawai dan penetapan berbagai tunjangan kesejahteraan pegawai.

2. Fungsi Pencatat Presensi Karyawan. Fungsi ini bertugas untuk mencatat kehadiran karyawan. Tetapi fungsi ini, telah dibantu dengan alat yang ada yakni menggunakan sensor sidik jari sehingga tidak perlu orang untuk mengawasi karyawan yang datang terlambat.

3. Fungsi Rekap Daftar Gaji/Fungsi Keuangan. Fungsi ini bertanggung jawab untuk membuat daftar gaji yang berisi penghasilan bruto yang menjadi hak dan berbagai potongan karyawan.

4. Fungsi Akuntansi. Fungsi Akuntansi bertanggung jawab mencatat kewajiban yang timbul, seperti utang-utang karyawan, dll. Selanjutnya fungsi ini akan mencatat ke jurnal umum dan memposting ke buku besar.

Dokumen Yang Digunakan oleh PT. Kerismas Witikco Makmur

1. Daftar Hadir (Kartu Absensi), dokumen yang digunakan untuk mencatat kehadiran karyawan. Daftar hadir dalam perusahaan telah menggunakan mesin sensor sidik jari (fingerprint) sehingga jam kerja karyawan tidak dihitung secara manual tetapi terlihat oleh mesin.

2. Daftar Gaji Karyawan, dokumen yang berisi jumlah gaji setiap karyawan.

3. Rekap Daftar Gaji, dokumen ini dibuat oleh fungsi pembuat daftar gaji bersamaan dengan pembuat daftar gaji yang berisi rincian besarnya gaji beserta potongan yang menjadi beban setiap karyawan.

4. Surat Pertanyaan Gaji, dokumen yang ditunjukan untuk menerangkan rincian gaji karyawan. Surat ini dibuat di bagian Personalia.

5. Bukti Kas Keluar, menyangkut bukti kas keluar ini merupakan perintah pengeluaran uang yang dibuat oleh fungsi akuntansi.

Catatan Akuntansi yang digunakan dalam Sistem Penggajian PT. Kerismas Witikco Makmur

Jurnal Umum, Buku Besar, dan Kartu Penghasilan Karyawan

Prosedur yang dilakukan dalam Sistem Penggajian

1. Prosedur pencatatan Waktu Hadir. Pengelolaan terhadap gaji dan upah ini selalu diawali dengan kegiatan setiap karyawan dalam mengisi informasi kehadiran agar diperoleh informasi mengenai waktu bekerja. Dan bagian ini telah dibantu dengan tenaga mesin yakni fingerprint.

2. Prosedur Pembuat Daftar Gaji. Dalam prosedur ini, bagian gaji membuat daftar gaji karyawan. Data yang dipakai sebagai dasar pembuatan daftar gaji adalah surat-surat keputusan mengenai pengangkatan karyawan baru, kenaikan pangkat, pemberhentian karyawan, penurunan pangkat, daftar gaji bulan sebelumnya, dan daftar hadir.

3. Prosedur Pembuatan Bukti Kas Keluar. Bukti kas keluar ini berfungsi sebagai perintah kepada fungsi kas untuk mengisi cek sebesar jumlah rupiah yang tercantum pada dokumen tersebut dan mengirimkan cek tersebut kepada kreditur yang namanya ditulis dalam dokumen tersebut.

4. Prosedur Pembayaran Gaji. Dokumen yang digunakan dalam proses ini adalah daftar gaji. Pada PT. Kerismas Witikco Makmur pembayaran gaji dilakukan melalui transfer antar bank yang telah bekerja sama dengan perusahaan.

\subsection{Pembahasan}

Sistem Penggajian pada PT. Kerismas Witikco Makmur masih menggunakan sistem manual. Tidak terdapat sistem komputerisasi yang khusus dalam sistem penggajian 
perusahaan manufaktur ini. Sesuai dengan Sistem Informasi Akuntansi yang di terapkan oleh perusahaan ini, maka penulis dapat memaparkan setiap unsur dalam sistem informasi ini, dapat diuraikan sebagai berikut :

1. Tujuan. Masalah gaji merupakan hal yang penting bagi suatu organisasi karena mempengaruhi tingkat prestasi, tingkat produktif kerja dan dedikasi karyawan kepada perusahaan. Oleh sebab itu perusahaan menjalankan sistem informasi penggajian untuk lebih 'transparan' kepada karyawan mengenai info gaji yang dihasilkan oleh setiap peagawai.

2. Masukan (Input). Sistem Penggajian memasukkan metode pencatatan atas pembayaran gaji yang sesuai dengan keputusan gaji karyawan pada saat pengangkatan pegawai.

3. Keluaran. Adanya keluaran berupa informasi yang berkualitas dan laporan-laporan yang berguna untuk tingkat manajemen dan semua pengguna informasi termasuk karyawan dalam PT. Kerismas Witikco Makmur.

4. Teknologi. Pada waktu ini dukungan teknologi komputerisasi pada perusahaan dan komunikasi sudah pada tingkat yang sedemikian rupa sehingga prosedur operasional yang lazim dikenal secara tradisional sudah berubah secara total, misalnya mengenai otorisasi, pembagian tugas, hubungan antar organisasi.

5. Basis Data. Data yang ada dalam basis data perlu disimpan untuk keperluan penyediaan informasi lebih lanjut. Perusahaan menyimpan segala data di perangkat keras komputer.

6. Pengendalian. PT. Kerismas Witikco Makmur memisahkan pabrik dan perusahaan kantor cabang agar seluruh proses keuangan dan sistem akuntansi penggajian lebih terfokuskan.

Selain unsur-unsur sistem informasi akuntansi yang telah terpenuhi, tujuan yang ingin dicapai dalam sistem penggajian juga telah terpenuhi. Hal ini dapat mendukung pengendalian internal atas penggajian yang tercermin dari tujuan sebagai berikut :

1. Memproses data menjadi informasi yang dapat digunakan dalam proses pengambilan keputusan terkait perencanaan dan pengendalian bisnis.

2. Melakukan kontrol secara tepat terhadap aset perusahaan termasuk efisiensi biaya dan waktu terhadap kinerja keuangan.

3. Sistem Informasi Akuntansi sangat mendukung pengambilan keputusan yang berguna bagi manajemen dalam pengambilan keputusan internal perusahaan.

Berdasarkan uraian di atas terlihat jelas bahwa unsur-unsur dan tujuan sistem informasi akuntansi yang diterapkan pada PT. Kerismas Witikco Makmur telah terpenuhi. Efektivitas sistem informasi akuntansi penggajian pada perusahaan PT. Kerismas Witikco Makmur dapat diketahui dari hasil uji metode Champion dan dari daftar pertanyaan yang ditujukan kepada 10 orang responden, didapat jawaban "Ya" sebanyak 250, dan jawaban "Tidak" 50, maka perhitungannya adalah :

$$
\frac{250}{(250+50)} \times 100 \%=83,33 \%
$$

Berdasarkan hasil perhitungan, menurut metode Champion nilai 83,33 \% menunjukkan bahwa sistem informasi akuntansi pada PT. Kerismas Witikco Makmur telah efektif.

\section{KESIMPULAN DAN SARAN}

\subsection{Kesimpulan}

Sistem penggajian yang diterapkan oleh PT. Kerismas Witikco Makmur yang terdiri dari prosedur, dokumen, dan catatan akuntansi yang digunakan dan fungsi yang terkait telah diberikan pengawasan yang baik dan pengendalian internal dalam menjalankan prosesnya. Keefektifan sistem informasi akuntansi dapat dilihat dari terdapat atau tidaknya unsur dan tujuan terkait sistem informasi akuntansi. Berdasarkan perhitungan menggunakan rumus 
Champion, nilai 83,33\% menunjukkan sistem informasi akuntansi pada PT. Kerismas Witikco Makmur dinyatakan efektif.

\subsection{Saran}

Sistem Akuntansi Penggajian yang dilaksanakan oleh perusahaan manufaktur yakni PT. Kerismas Witikco Makmur ini sudah dijalankan dengan baik, tetapi sebaiknya diberlakukan pemisahan fungsi antara pencatatan dan penetapan gaji karyawan. Tidak terdapatnya prosedur distribusi biaya gaji dan upah kepada setiap departemen membuat sistem penggajian pada perusahanaan mengalami keterlambatan sehingga perusahaan perlu menjalankan salah satu prosedur ini. Hal ini berguna untuk mempermudah tugas dan tanggung jawab departemen, serta data yang dihasilkan tepat dan cepat waktu juga akurat.

\section{DAFTAR PUSTAKA}

Azhar, S. 2013. Sistem Informasi Akuntansi. Bandung : Lingga Jaya

Baridwan, Z. 2012. Sistem Akuntansi: Penyusunan Prosedur dan Metode. Edisi Kelima. Yogyakarta: BPFE.

Bodnar, G. H. and Hopwood, W. S. 2010. Accounting Information System. 10th edition. United State Of America: Pearson Education Inc.

Gelinas, Ulrich \& Dull, Richard, B. 2012. Accounting Information Systems. 9th ed. South Western Cengage Learning. USA : 5191 Natorp Boulevard Mason

Hery. 2014. Pengendalian Akuntansi dan Manajemen. Jakarta: Kencana

Moleong. L. 2009. Metode Penelitian Kualitatif. Bandung: PT. Remaja Rosdakarya.

Mulyadi. 2016. Sistem Akuntansi. Edisi Ke Empat. Jakarta : Salemba Empat.

Reeve J M., Warren C S., dan Duchac, J. 2011. Pengantar Akuntansi: Adaptasi Indonesia. Buku 1, Alih Bahasa: Damayanti Dian, Salemba Empat, Jakarta.

Rivai, V. 2010. Manajemen Sumber Daya Manusia Untuk Perusahaan. Jakarta: PT. Rajagrafindo Persada.

Romney, M. B dan Steinbart, P. J. 2015. Accounting Information Systems. 13th ed. England : Pearson Educational Limited.

Walgito, B. 2010. Pengantar Psikologi Umum. Yogyakarta : Penerbit Andi.

Yakub. 2012. Pengantar Sistem Informasi. Yogyakarta: Graha Ilmu. 